\title{
Clarifying the Disruptive Innovation Puzzle: A Critical Review
}

\section{Introduction}

The theory of disruptive innovation (DI) has attracted much attention, has been widely analysed in the literature in the last 20 years (1985-2017) and continues to attract both scholarly interest and popular attention (Ansari et al., 2016). There is widespread use of the term "disruptive innovation" within academia and industry (Tellis, 2006; White, 2017; Yu and Hang, 2010) and a business which disrupts the market and is deemed economically successful is commonly viewed as an "agile" effective business (Taylor, 2017). Christensen's work (well-known as the pioneer of this theory) has been cited extensively by scholars in diverse disciplines and research fields, including marketing, strategy, and technology and innovation management (Vecchiato, 2017). It has been widely applied to many different industries, such as airlines, transportation, consumer buying, and more recently, 3D printing (Allahar, 2017; Hahn et al., 2014). The impact of DI is enormous, companies operate their business using this theory, potentially transforming business and society at large and it is the axis of many transformations. Researchers and practitioners are thus increasingly interested in understanding how companies can either create or compete against DI.

In the mid-1990s, the winds of change blew with great force and intense competition, even threatening some of the strongest companies, according to Clayton M. Christensen, a professor at Harvard Business School. In his 1997 book, The Innovator's Dilemma, he provided an explanation for the failure of respected and well-managed incumbents. Good managers are faced with a dilemma, he argued, because by doing the same things (i.e., 
listening to their customers, investing in the business, and creating distinctive capabilities that would provide their customers more and better products of the sort they wanted), they run the risk of ignoring "disruptive innovations (DIs)" and lose their positions of leadership, because DI proposes that there are times at which it is right not to listen to customers, right to invest in developing lower-performance products that promise lower margins, and right to aggressively pursue small, rather than substantial, markets. In this context, some innovations have the potential to disrupt the market for competing products and services, while others sustain the competitive position of incumbent firms (Hang et al., 2015). By focusing on maintaining their competitive position, established incumbents open the door for new entrants to identify business opportunities and to introduce DIs.

A DI attacks an existing business, offering great opportunities for new profit growth (Assink, 2006) and requiring major changes in established business models (Kranz et al., 2016). It results in a substantial change in the market (Assink, 2006). DI arises from globalisation, technological advances, and cultural changes, and a change always presents threats and offers opportunities (MacFeely, 2016). Such has been its influence that this theory has affected businesses in varied and complex ways. In Silicon Valley disruption has become a mantra, a call for action, and instead of using the word "innovation" now just refers to disruption and disruptors (Hogarth, 2017). Notwithstanding its huge influence, this theory has not been universally accepted among business theorists (Steenhuis and Pretorius, 2017; Weeks, 2015). Its definition remains somewhat vague, as a specific innovation characteristic, or set of characteristics, is not identified (Nagy et al., 2016). Therefore, a singular definition of DI is difficult to identify and there is still not sufficient research for a clear understanding of this theory (Assink, 2006; White, 2017). 
Likewise, Christensen et al. (2015) have also recognised that there is still much to be learnt, and are eager to continue expanding and refining the theory. More importantly, DI has been used outside the context of its specific definition has been widely misunderstood and its basic tenets frequently misapplied (Christensen et al., 2015; Steenhuis and Pretorius, 2017). This concern is shared by other researchers who claim that the definition of DI is routinely misused or improperly broadly applied in research (Danneels, 2004; Kushins et al., 2017; Markides, 2006; Tellis, 2006; Yu and Hang, 2010). The term disruptive is often misunderstood and can be so easily misconstrued, and despite the ubiquity of the term, managers often have a hard time identifying a DI (Schmidt and Druehl, 2008).

In common language the meaning of the word disrupt is associated with the idea of "interrupting the continuity of; bringing disorder to; breaking apart." Thus, the meaning of the term "disruptive" and a lack of understanding of DI theory can also be a barrier to arriving at a common understanding of what it is. In other words, the absence of a clear definition and the imprecision with which the term is employed create confusion among those striving to understand, implement and develop optimum business strategies, and lead to errors. Christensen (1997) argued that DI is intended to help a wide range of managers, in slowly evolving or rapidly changing environments. A better recognition of DIs by managers will lead to a new dominant logic that pursues new strategic actions (Gholampour, 2017). Consequently, a clear definition of DI is still one of the major hurdles to be overcome.

Nevertheless, this situation has not stopped the development of a broad-based body of literature examining the theory. Sufficient literature exists about the various aspects and 
facets of DI. Many of the works are empirical cases studies, and very few studies have been published that attempt to understand what is meant when we talk about DI (e.g. Christensen et al., 2015; King and Baatartogtokh, 2015; Schmidt and Druehl, 2008; Yu and Hang, 2010). Taken together all the previous point of views, one critical goal in our review involves the definition of DI and providing a clear and comprehensive framework for the theory.

Another important point is that the importance of DI arises from its potential impact on the fortunes of incumbent and start-up firms, as well as the opportunities created for new entrants in both existing and new markets (Parry and Kawakami, 2017). Thus, the key idea behind DI is that incumbents are focused on improving products and services for their most demanding, and usually most profitable, customers thereby exceeding the needs of some segments. Entrants' early technologies have inferior capabilities and begin by successfully targeting the overlooked lower-end segments, so that over time capabilities improve, and they move up-market, delivering the performance that incumbent mainstream customers require (Steenhuis and Pretorius, 2017). Inferring from Christensen (1997) and Christensen and Raynor (2003) entrants with DIs threaten the existence of leading incumbents in the market. Consequently, this part introduces the second goal of determining what actions are taken by incumbents, entrants and customers (actors of DI) under this theory.

Therefore, a study based on a critical review would clearly represent a timely addition to the literature, delivering information about current thinking on important aspects of this theory and identifying the lessons that DI has to offer researchers and practitioners. 
In this context, the main aim of our work is to conduct a review of DI, identifying major works in order to answer two research questions: (1) What is DI? We conduct an analysis by focusing on three broad categories: the evolution of this theory (antecedents and definitions), typology and characteristics and 2) What behaviours are adopted by the actors associated with DI (that is, incumbents, entrants and customers)?

DI is gaining increasing interest among researchers and business practitioners, and so researchers can use this study to understand the state of the art in DI, and practitioners can find an instrument for developing strategies, and business models, and take advantage of an opportunity or a way to survive over time. A deeper understanding of this theory could contribute to better decisions and counteract the risk inside the business world.

Our research is important for four reasons. First, as noted above "disruptive innovation" is used by researchers and practitioners, but there is no clear understanding of what exactly it means; what are the tenets supporting this theory? This article provides insight into this theory from the time of its birth, through evolution and recent research advances. Second, this currently fashionable theory is affecting many businesses, the process that DI follows between incumbents, entrants, and customers can help managers implement effective early strategies to respond to this kind of innovation. Third, this article examines the phenomenon of disruption and complements perspective and insights into the state of DI theory in order to facilitate an easy understanding and identification of its basic principles. Fourth, this analysis contributes to clarifying the present state of knowledge of DI and can help to establish a common theoretical ground. 
Subsequent to this introduction, this article is structured as follows. First, we set out the methodology used in conducting our review. Second, we report the results obtained to answer our two research questions. Third, we discuss our main results. Finally, the last section is devoted to conclusions.

\section{Research Methodology}

This article presents a critical review of DI. This section explains the literature research method taken in order to address our research questions. We developed an exhaustive coverage approach in order to ensure that all relevant studies were included in the review. Ours process of analysis comprised the following steps: definition of a search strategy, selection of key words, research period, definition of inclusion and exclusion criteria, and process of selection of the articles applying the criteria.

1) Search strategy. Web of Science was the main database used for the literature research for the most comprehensive results.

2) Key words. We used the key words related to this DI theory. The data sources were searched using the Boolean search terms of "disrupt* innovat*."

3) Research period (Articles retrieved). We conducted the research from 1964 to 2017 so as to determine the chronological evolution of DI.

A total of 934 documents were retrieved. The analysis included journal articles (647) published up to 1985 (inclusive); before this date we found no articles about DI. Therefore, our study does not include sources such as reviews, letters, news, and other documents that report on this kind of innovation. Journal articles are widely considered the repositories of valid knowledge (e.g. Ordanini et al., 2008; 
Podsakoff et al., 2005; Savino et al., 2017) and additionally, we included five seminal books related to the theory: two published by the author of the theory (Christensen, 1997; Christensen and Raynor, 2003) one on creative destruction (Schumpeter, 1942), and the other two linked to the hierarchy of needs (Maslow, 1954) and the diffusion of innovations (Rogers, 2003). The 934 documents were analysed following the steps established in Figure 1.

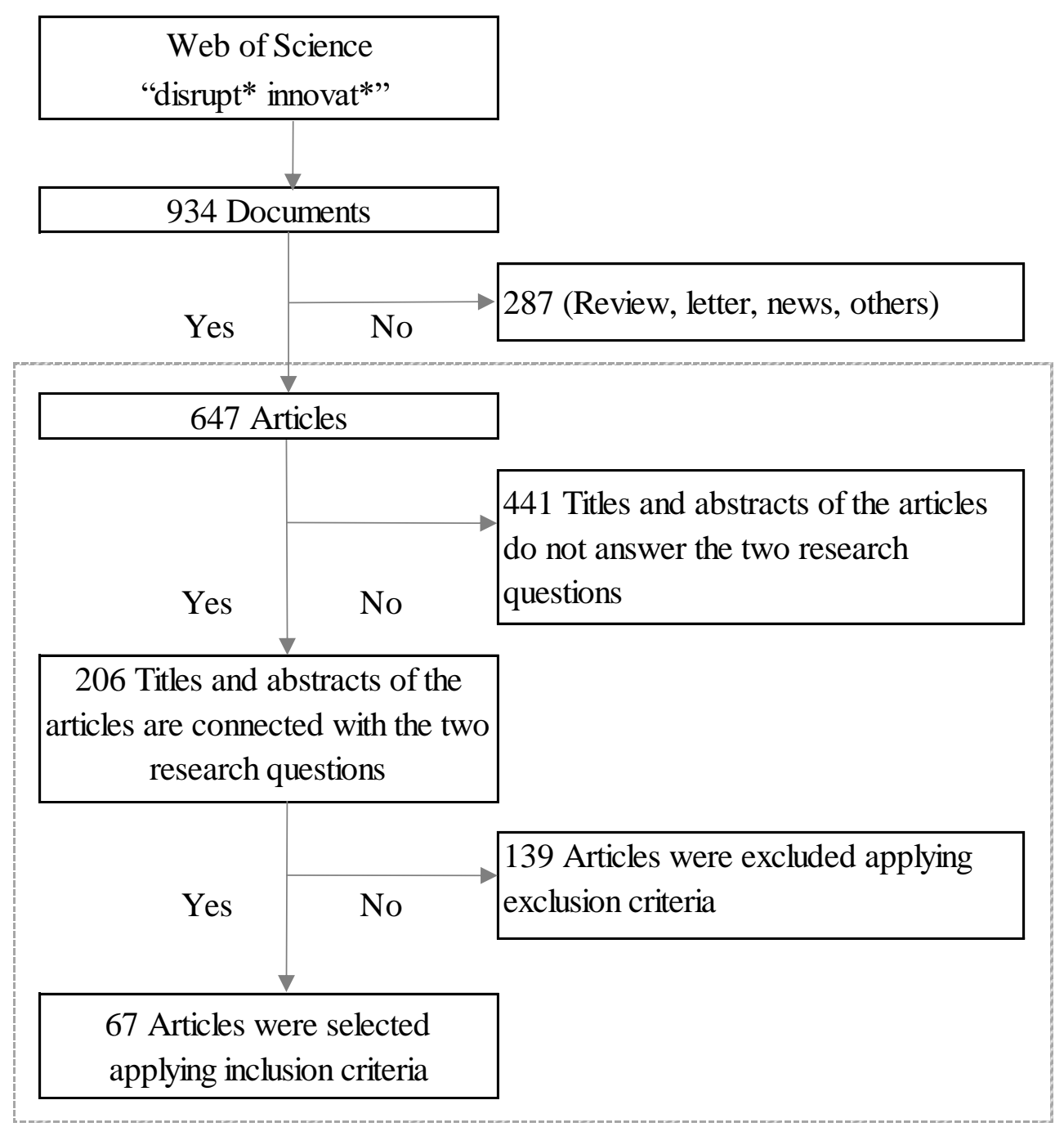

Figure 1. Steps followed to select the final sample of articles

All 647 articles constitute reports on DI theory. Within our defined objectives, this work advances the critical review of DI theory, since its first antecedents and its 
conceptualisation. Figure 2 shows the evolution in the number of articles dedicated to DI theory.

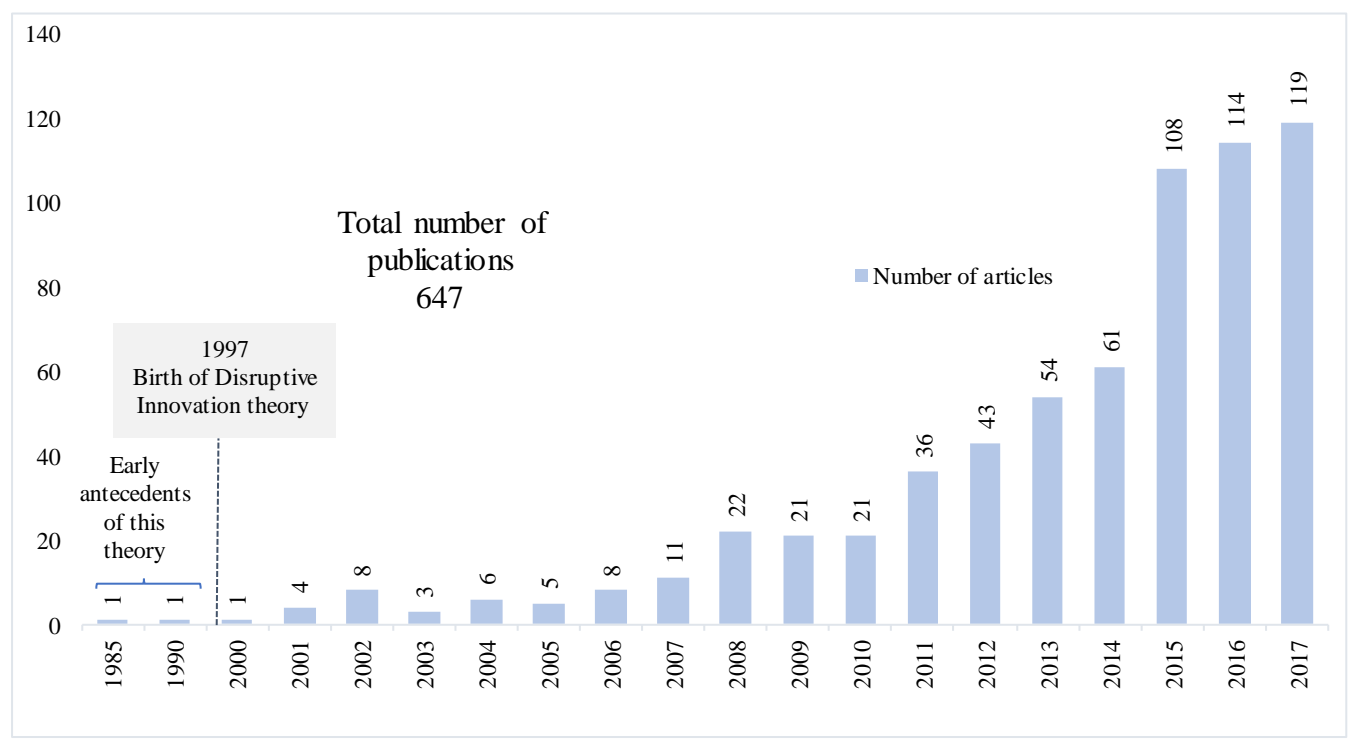

Figure 2. Number of articles on disruptive innovation by year

As reported in Figure 2, the number of publications has increased markedly since 2011. Indeed, between 2014 and 2017, the number of articles almost doubled in number (from 61 to 119), highlighting the emerging nature of the theory of DI. Figure 3 shows the 20 main research areas in which these 647 articles were published. 


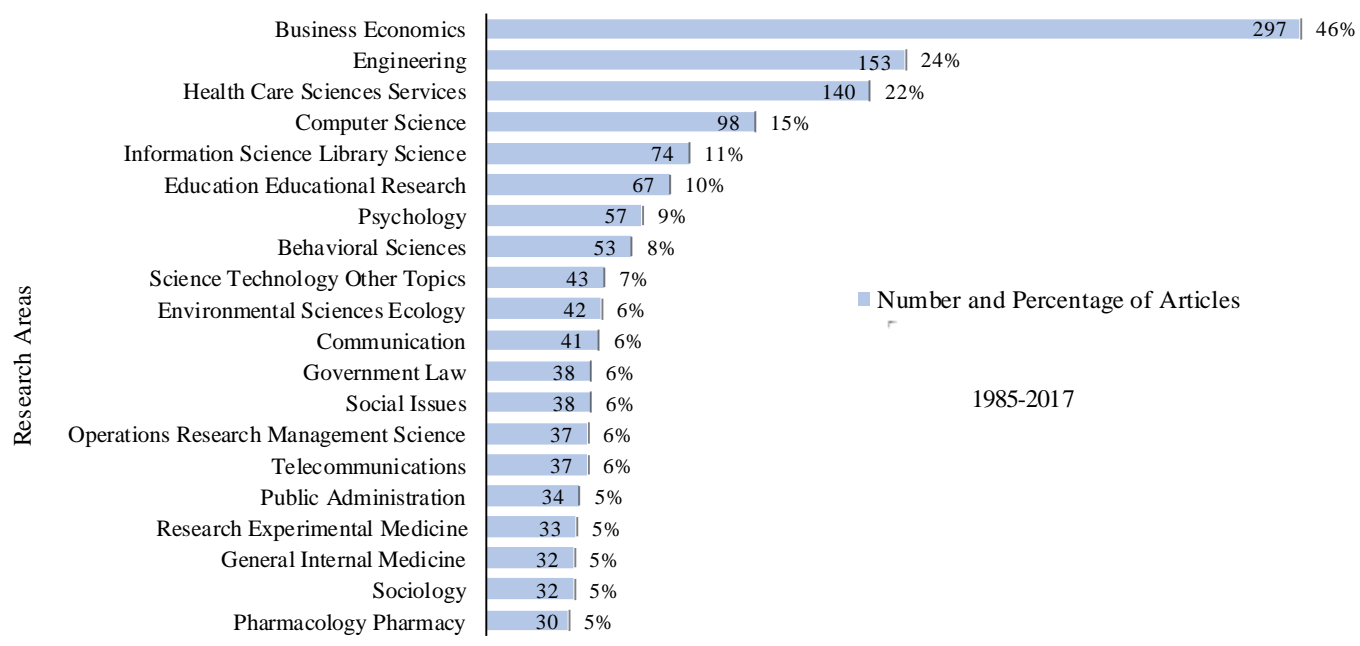

An article can be connected to two or more research areas because a journal can report on several areas and therefore the percentage of each research area shows the percentage with respect to the total of 647 articles (i.e. 647 represent the $100 \%$ in each area).

Figure 3. Articles on disruptive innovation by research area

The highest percentage of publications on DI is concentrated in Business Economics $46 \%$ (297 from a total of 647 articles), followed by engineering $24 \%$ (153 articles). Clearly, DI has greatest relevance in the business world but there are many other research areas that have been receptive to DI.

4) Definition of inclusion and exclusion criteria. When defining criteria for article selection, we did not restrict our search to specific fields, on the understanding that DI theory has been applied to many areas of research. We included all research areas to ensure we captured all definitions, characteristics and so on, to answer our research questions. In selecting the articles, we took both theoretical and empirical studies into account. An iterative process of analysis between the research questions established and theoretical approaches of the revised articles was carried out. From that process selection criteria arise that then were grouped into inclusion and exclusion criteria established in Table 1. 


\begin{tabular}{ll}
\hline Inclusion criteria & Exclusion criteria \\
\hline $\begin{array}{l}\text { DI is the article's main topic } \\
\text { Focus on the importance of DI }\end{array}$ & $\begin{array}{l}\text { Focus on other kinds of innovation } \\
\text { Focus on the potential benefits of DI }\end{array}$ \\
$\begin{array}{l}\text { Focus on exploring or referring to examples that may be } \\
\text { future examples of DI }\end{array}$ \\
$\begin{array}{l}\text { Focus on the impact of DI } \\
\text { Focus on an analysis of examples of DI }\end{array}$ & $\begin{array}{l}\text { Focus on unit analysis or a specific topic other than DI } \\
\text { (e.g. ecology, medicine, nursing, education, law, }\end{array}$ \\
Focus on factors that influence DI & technology, social media, big data and social change) \\
Focus on potential cases of DI & DI is mentioned but not analysed \\
& Not possible to determine actual focus on DI \\
\hline
\end{tabular}

Table 1. Inclusion and exclusion criteria

The inclusion criteria were all sufficiently inclusive to identify the most relevant articles for responding to our two questions, and the exclusion criteria were exclusive enough to eliminate less relevant articles.

5) Applying the inclusion and exclusion criteria. After reviewing the 206 articles against the inclusion and exclusion criteria, we were left with 67 relevant articles. Of the 67 articles studied here 76\% (51) are empirical studies and the remaining $24 \%$ (16) are theoretical studies. Not surprisingly, the majority of the empirical studies $84 \%$ (43 articles) are published in journals related to business economics (business economics $29 \%$ (15), business economics, engineering, computer science, information science library science, education educational research, mathematics, geography, government law, and other topics 55\% (28)). The remaining $16 \%$ (8) are concentrated in the health care sciences services. It is worth noting that a high percentage of the theoretical articles are published in business research and engineering research areas $81 \%$ (13), the rest of the articles $19 \%$ (3) are published in health care sciences services, arts humanities other topics, mathematics, social sciences and sociology research areas. 


\section{Results}

This section examines the two research questions raised by our research.

\section{What is DI?}

In recent years, researchers have used several standards to classify or explain DIs. The importance of accurately understanding DI theory has been debated in many studies. In this section we provide an analysis of the articles reviewed in order to accentuate and reinforce a definition of disruptive innovation. To do this, we have divided this section in three parts: evolution of the theory, types of DI and the main characteristics of this kind of innovation.

Evolution of DI. The theory of 'creative destruction' developed by Schumpeter (1942), was the guide for early works focusing on examples related to the role of technology in competitiveness (e.g. Abernathy and Clark, 1985; Bower and Christensen, 1995; Christensen and Bower, 1996; Henderson and Clark, 1990). Figure 4 shows a timeline of the antecedents of DI theory.

\begin{tabular}{|c|c|c|c|c|}
\hline Innovation & Early & focused & disruptive technologie & \\
\hline Book & \multicolumn{4}{|c|}{ Articles } \\
\hline 1942 & 1985 & 1990 & 1995 & 1996 \\
\hline Schumpeter & Abernathy \& Clark & Henderson \& Clark & Bower and Christensen & Christensen \& Bower \\
\hline$\sqrt{7}$ & $\sqrt{2}$ & 7 & $\sqrt{2}$ & $\checkmark$ \\
\hline $\begin{array}{l}\text { Theory of economic innovation and } \\
\text { the business cycle. The "gale of } \\
\text { creative destruction" } \\
\text { First. Every element takes considerable } \\
\text { time in revealing its true features and } \\
\text { ultimate effects. Second: Every piece of } \\
\text { business strategy acquires its true } \\
\text { significance only against the } \\
\text { background of that process and within } \\
\text { the situation created by it. } \\
\text { Revolutionizes the economic structure } \\
\text { destroying the old one, creating a new } \\
\text { one. }\end{array}$ & $\begin{array}{l}\text { Some innovations disrupt, } \\
\text { destroy and make obsolete } \\
\text { established competence; others } \\
\text { refine and improve. } \\
\text { Technological innovation may } \\
\text { influence a variety of economic } \\
\text { actors in a variety of ways. } \\
\text { Firms compete by offering } \\
\text { products that may differ in many } \\
\text { aspects: performance, reliability, } \\
\text { availability, ease of use, aesthetic } \\
\text { appearance, and image as well as } \\
\text { initial cost. }\end{array}$ & $\begin{array}{l}\text { Architectural } \\
\text { innovations } \\
\text { (technological } \\
\text { products) destroy } \\
\text { the usefulness of the } \\
\text { architectural } \\
\text { knowledge of } \\
\text { established firms. }\end{array}$ & $\begin{array}{l}\text { Disruptive Technologies } \\
\text { introduce a very different } \\
\text { package of attributes from the } \\
\text { one mainstream customers } \\
\text { historically value and they } \\
\text { often perform far worse along } \\
\text { dimensions that are important } \\
\text { to those customers. } \\
\text { Management needs to be aware } \\
\text { of ignoring new technologies. }\end{array}$ & $\begin{array}{l}\text { Disruptive Technologies } \\
\text { tend to be saleable only in } \\
\text { different markets whose } \\
\text { economic and financial } \\
\text { characteristics render them } \\
\text { unattractive to established } \\
\text { firms. Established firms fail } \\
\text { to develop simpler } \\
\text { technologies that initially } \\
\text { are only useful in emerging } \\
\text { markets. }\end{array}$ \\
\hline
\end{tabular}

Figure 4. Timeline of antecedents of disruptive innovation theory 
In 1997 DI theory was proposed by Christensen within a broader technological conceptual framework. He argued that a sort of technological change, called disruptive technologies, was what toppled the industry's leaders. At that time, he argued that the principles of DI show that when good companies fail, it has often been because their managers either ignored these principles or chose to fight them. In early works, he refers to disruptive technology as an "innovation that results in worse product performance in relation to mainstream markets" (Corsi and Di Minin, 2014). This first definition was focused on examples of technologies whose characteristics were simpler, cheaper, and affordable with good enough performance compared with incumbents' products. A few years later, Christensen and Raynor (2003) changed the term "disruptive technology" to "disruptive innovation" and widened the application of the theory to include not only technological products, but also services and business models (Dijk et al., 2016; Markides, 2006; Wan et al., 2015; Yu and Hang, 2010). Figure 5 shows two key milestones in the birth of DI theory.

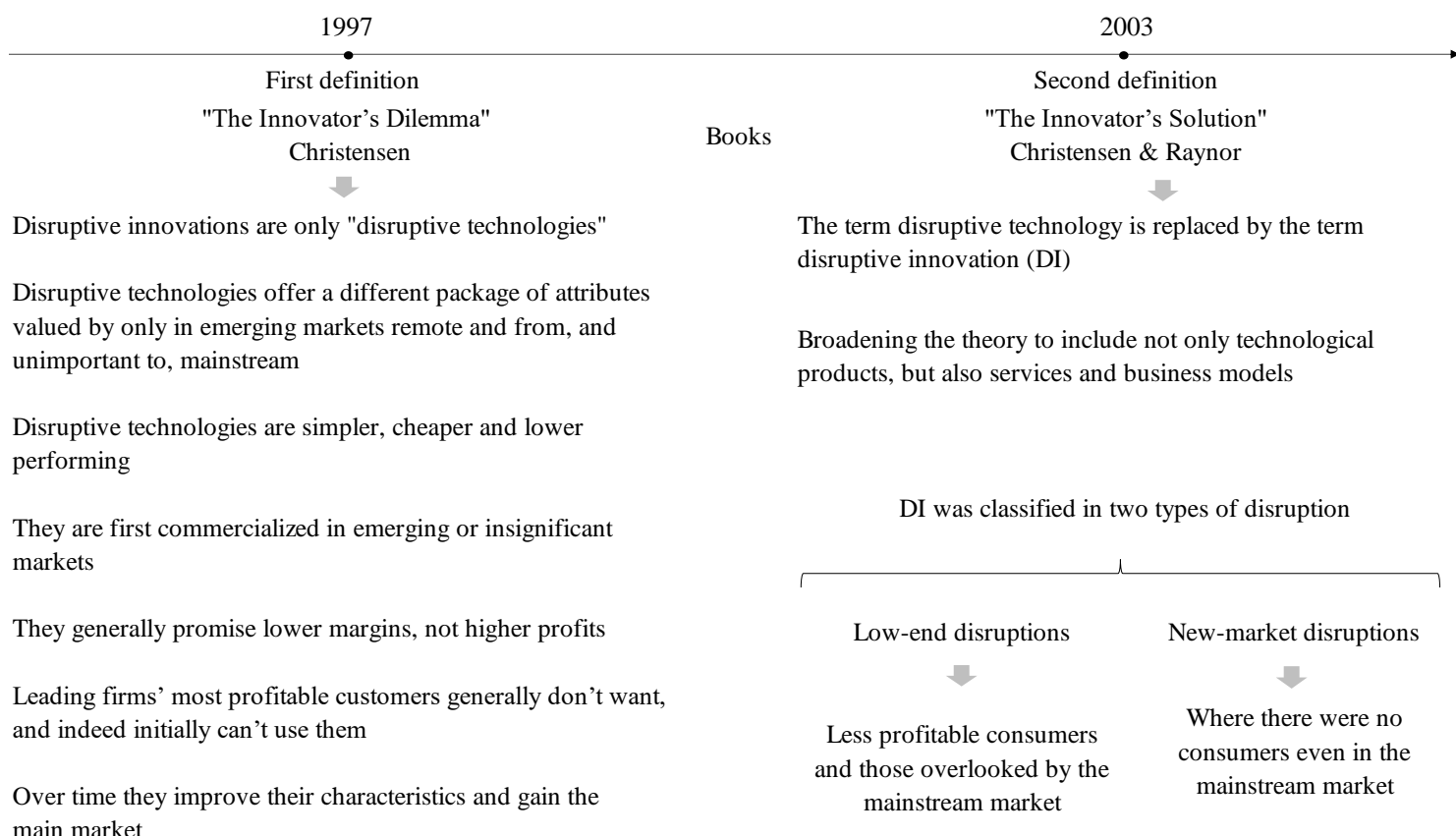

Figure 5. The birth of disruptive innovation theory 
From a historical point of view, as Figure 5 highlights, different elements have enabled us to identify DIs. There are two clear stages in the definition of a DI, each being typified by one key insight. This has led to some confusion, with some researchers employing only the first definition and others the second: for example, in studies referring to a technological innovation, some researchers employ the first definition (the first book focused particularly on disruptive technologies, and some researchers use this term and its definition, where DIs were only disruptive technologies) while others employ the second (DIs are not limited to technologies). The theory has been complemented in its development by other studies, but over time, the same theory has been used to explain all kinds of DIs, resulting in mistakes (Markides, 2006). As Christensen et al. (2015) argued, people too frequently use the term loosely to invoke the concept of innovation in support of whatever it is they wish to do and many researchers, writers, and consultants use "disruptive innovation" to describe any situation in which an industry is shaken up and the previously successful incumbents stumble, arguing that this is a much too broad usage. In line with Christensen's concerns Steenhuis and Pretorius (2017) pointed out that this theory has been widely misunderstood and its basic tenets frequently misapplied. Indeed, the existence of a first and second definition, the understanding of the term "disruptive" and the complexity of this theory, have all caused misunderstandings.

Table 2 shows a summary of definitions, and their evolution, as employed by different researchers working in this field. Our review found 17 definitions of DI. As is seen in the next table, when researchers give a definition of DI, they either quote Clayton Christensen's theory, or offer their own definition. We also identified three perspectives on these definitions. 


\begin{tabular}{|c|c|c|c|}
\hline Perspectives & $\mathbf{N}^{o}$ & Definitions of Disruptive Innovation (DI) & Guiding references \\
\hline $\begin{array}{l}\text { DI } \\
\text { Can change the bases } \\
\text { of competition }\end{array}$ & 1 & $\begin{array}{l}\text { DI represents a process where a product establishes itself } \\
\text { at the bottom of a market and climbs through this sector to } \\
\text { displace competitors }\end{array}$ & $\begin{array}{l}\text { Christensen (1997), } \\
\text { Tan et al. (2016) }\end{array}$ \\
\hline \multirow[t]{5}{*}{$\begin{array}{l}\text { A process that } \\
\text { transforms the market } \\
\text { Creator of a new } \\
\text { business or market }\end{array}$} & 2 & $\begin{array}{l}\text { DI is a successfully exploited radical new product, } \\
\text { process, or concept that significantly transforms the } \\
\text { demand and needs of an existing market or industry, } \\
\text { disrupts its former key players and creates whole new } \\
\text { business practices or markets with significant societal } \\
\text { impact }\end{array}$ & Assink (2006) \\
\hline & 3 & $\begin{array}{l}\text { This theory outlines a process through which a disruptive } \\
\text { product transforms a market, sometimes to the point of } \\
\text { upending previously dominant companies }\end{array}$ & Guttentag (2015) \\
\hline & 4 & $\begin{array}{l}\text { DI changes the performance metrics, or consumer } \\
\text { expectations, of a market by providing radically new } \\
\text { functionality, discontinuous technical standards, or new } \\
\text { forms of ownership }\end{array}$ & Nagy et al. (2016) \\
\hline & 5 & $\begin{array}{l}\text { The term refers to innovations that create new markets and } \\
\text { value networks while disrupting existing ones }\end{array}$ & Tham (2016) \\
\hline & 6 & $\begin{array}{l}\text { Theory of change, prioritizes conflict, discontinuity, and } \\
\text { constant alterity over sustainability, memory, and } \\
\text { community }\end{array}$ & Levina (2017) \\
\hline \multirow[t]{5}{*}{$\begin{array}{l}\text { DI } \\
\text { As a low-cost model } \\
\text { ("Good enough" } \\
\text { performance and at low- } \\
\text { cost) }\end{array}$} & 7 & $\begin{array}{l}\text { DI describes how companies may falter not by falling } \\
\text { behind the pace of advancement or ignoring their core } \\
\text { consumers, but rather by disregarding the upward } \\
\text { encroachment of a disruptive product that lacks in } \\
\text { traditionally favoured attributes but offers alternative } \\
\text { benefit }\end{array}$ & $\begin{array}{l}\text { Bower and Christensen } \\
\text { (1995), Christensen (1997, } \\
\text { 2006), Christensen and } \\
\text { Raynor (2003), Schmidt and } \\
\text { Druehl (2008), Guttentag } \\
\text { (2015) }\end{array}$ \\
\hline & 8 & $\begin{array}{l}\mathrm{DI} \text { is founded as a low cost model to depose of its } \\
\text { competitors operating with a higher cost structure }\end{array}$ & $\begin{array}{l}\text { Markides (2006), } \\
\text { Tham (2016) }\end{array}$ \\
\hline & 9 & $\begin{array}{l}\text { DI introduces a different set of features, performance, and } \\
\text { price attributes relative to the existing products, a } \\
\text { combination that is unattractive to mainstream customers at } \\
\text { the time of product introduction (due either to inferior } \\
\text { performance on the attributes that mainstream customers } \\
\text { value and/or a high price) }\end{array}$ & Govindarajan, et al. (2011) \\
\hline & 10 & $\begin{array}{l}\text { DI as relevant to an understanding of the dynamics of } \\
\text { innovation and the actions by firms in introducing lower- } \\
\text { performing, lower-cost products that can gain market share }\end{array}$ & Weeks (2015), Allahar (2017) \\
\hline & 11 & $\begin{array}{l}\text { DI is described as: simple, cheap, small, and easy-to-use } \\
\text { products or services that cater to the need of the unserved } \\
\text { or underserved market and has the potential to increase } \\
\text { revenue by developing an altogether new market }\end{array}$ & Agarwal et al. (2017) \\
\hline \multirow{6}{*}{$\begin{array}{l}\text { DI } \\
\text { Taking into account } \\
\text { technology }\end{array}$} & 12 & $\begin{array}{l}\text { A DI is a technology, product, or process that creeps up } \\
\text { from below an existing business and threatens to displace it }\end{array}$ & Rafii and Kampas (2002) \\
\hline & 13 & $\begin{array}{l}\text { DI refers to technological innovations, new products, or } \\
\text { new services that require a "disruptive" strategic reaction } \\
\text { that often serves to overtake the prevailing dominant } \\
\text { technologies or status quo products in a market }\end{array}$ & $\begin{array}{l}\text { Christensen (2006), } \\
\text { Crockett et al. (2013) }\end{array}$ \\
\hline & 14 & $\begin{array}{l}\text { Disruption should be seen as a process whereby small } \\
\text { companies (entrants) are able to challenge established } \\
\text { incumbent firms by offering new technology often at a } \\
\text { lower price to overlooked customer segments }\end{array}$ & $\begin{array}{l}\text { Christensen et al. (2015), } \\
\text { Pérez et al. (2017) }\end{array}$ \\
\hline & 15 & $\begin{array}{l}\mathrm{DI} \text { is a product that is based on a disruptive technology } \\
\text { and delivers superior performance on attributes valued by } \\
\text { mainstream markets }\end{array}$ & Parry and Kawakami (2017) \\
\hline & 16 & $\begin{array}{l}\text { DI usually commences with complex business models } \\
\text { involving sophisticated products and dominant } \\
\text { technologies, but with incremental perfection of the } \\
\text { product/service and technological improvements to suit } \\
\text { diverse tastes, the less dominant, inexpensive product } \\
\text { expanses its market share and ultimately takes over the } \\
\text { market }\end{array}$ & Rambe and Moeti (2017) \\
\hline & 17 & $\begin{array}{l}\text { DI as "technology that changes the bases of competition } \\
\text { by changing the performance metrics along which firms } \\
\text { compete" (Danneels, 2004) and may be capable of radical } \\
\text { change, but it is not necessarily a driver of instantaneous } \\
\text { change }\end{array}$ & White (2017) \\
\hline
\end{tabular}

Table 2. Disruptive innovation definitions 
Researchers do not use the same definition as we can see in Table 2. From our point of view, the different perspectives on the definitions of DI can be briefly summarised as three main approaches: 1) DI is a process that has a disruptive potential to transform or induce changes in markets, 2) DI as a low-cost model and 3) DI as a process where the use of technology to deliver a better product is a key issue. This recognition of the role of technology may have arisen because researchers use the first definition of the DI theory or because their studies focus specifically on examples that use technology to develop this sort of innovation. On the whole, all these definitions complement each other, but there is no common definition. Perhaps the complexity of the phenomenon makes agreement difficult.

It is also noteworthy that many researchers agree that DI is a process (Ansari et al., 2016; Assink, 2006; Christensen, 1997; Christensen et al., 2015; Contandriopoulos et al., 2016; Guttentag, 2015; Isherwood and Tassabehji, 2016; Pérez et al., 2017; Tan et al., 2016; Yu and Hang, 2010) not an event, and the process can take a long time, up to decades to unfold (Flavin, 2016a). Other researchers take into account the core of this theory, as described by Christensen, and argue that "DI usually starts off as an inferior product but provides value through the application of new technologies and business models that enhance access to a new service or product while disrupting the market" (Allahar, 2017; Lewis, 2012). Other researchers suggest that DI is possible where a technology is in its infancy and the market is ill defined, leading companies to embark on an iterative market testing process involving the launch of various versions of the product, in order to deliver affordable, innovative, and high-tech products with minimal capital investments (Gurca and Ravishankar, 2016). 
Despite efforts to bring the definitions in line, no consensus has been reached in the literature. Although various researchers define DI in accordance with Christensen's proposal, others modify or complement it, adding the conclusions drawn from their own specific studies.

To sum up, based on our review, DI can be seen as a process that takes place over periods of time, which starts in the low-end market or creates a new market to move up toward the mainstream market and high-end market. A DI does not initially compete with incumbents, but after some time competition intensifies, often resulting in the displacement of the traditional incumbents or in the sharing of the market, although the DI typically enjoys a larger market share, offering products or services with unique characteristics that make it a better choice for consumers. DI can initially only be used in small markets distant from the mainstream market, is disruptive because it can subsequently become fully performance-competitive against established products or services within the mainstream market and can change the behaviours of customers, incumbents and the market. Figure 6 illustrates the scope of our definition of DI.

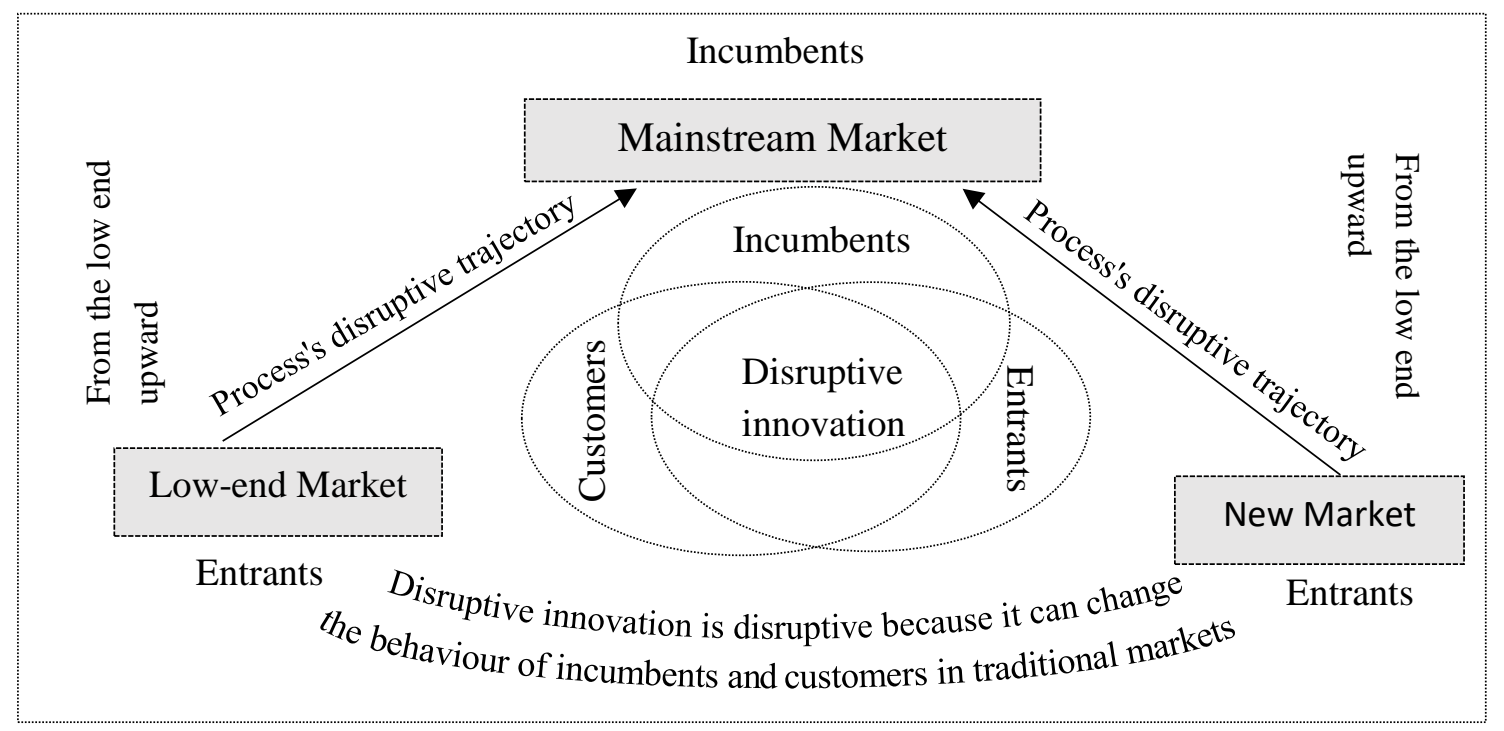

Figure 6. Disruptive innovation definition 
Types of DI. The literature identifies two types of DI: low-end and new-market disruptions.

Based on these broad types, we argue that:

Low-end disruptions are those that attack the least-profitable and most overserved customers, begin in a low-end market, with inferior performance as regards traditional attributes and by offering a low price and design simplicity (Christensen, 1997; Christensen and Raynor, 2003; Govindarajan and Kopalle, 2006; Yu and Hang, 2010). These innovations are designed for customers for whom the incumbent's offer provides excess functionality at unaffordable prices. Hang et al. (2015) argue that such disruptions are associated with the strategies of opportunities discovery. Incumbents pay less attention to less-discerning customers and typically offer their products/services to their most profitable, more discerning customers. This opens the door to a disruptor, focused (initially) on low-end customers and providing a "good enough" product, to later move up to the mainstream market. This does not result in better product performance; rather, it serves users who are attracted by low prices (Dijk et al., 2016).

The low-end disruption paradigm does not create a new market, but rather changes the existing market's game; it is based on the existing mainstream value networks and introduces similar products or services at lower cost and price (Chen et al., 2017), and that cost is substantially lower (Nagy et al., 2016). The first customers are part of the existing market segment with similar performance criteria to mainstream customers but with lower purchasing power (Dedehayir et al., 2017; Schmidt and Druehl, 2008). Therefore, customers from the low-end market therefore consider it a good option to accept lower performance at a more affordable price. Here it is also important to consider 
the factors influencing this innovation, such as cooperation with venture capitalists, external knowledge sources, the dominant position of $\mathrm{R} \& \mathrm{D}$, and willingness of entrepreneurs to innovation (Chen et al., 2017).

New-market disruptions begin with the least-demanding tier and compete against nonconsumption, are specifically focused on creating consumption, and are disruptions that create a new value network (Christensen and Raynor, 2003). These innovations provide products with a different group of features from the mainstream product (Guo et al., 2016) for customers who "had not owned or used the prior generation of products or services" (Hang et al., 2015) or new users (Dijk et al., 2016). Dedehayir et al. (2017) argue that, unlike low-end disruptions, new market disruptions do not necessarily compete on lower price, adding that many disruptive changes are hybrids of low-end and new market disruption (e.g., Canon Photocopier). Schmidt and Druehl (2008) refined new market disruption into two types: fringe-market low-end encroachment and detached-market low-end encroachment.

Govindarajan and Kopalle (2006) describe low-end disruption as being technologically less radical and high-end disruption as being technologically more radical. Here, our focus is on high-end disruption because we believe it can be developed within this type of new-market disruption. This is the less price sensitive segment, providing inferior performance in terms of traditional attributes, at a high price such as in mobile phones (Govindarajan and Kopalle, 2006; Yu and Hang, 2010). These are products based on a disruptive technology that are initially offered at a premium price to price-insensitive customers served by the dominant technology (Parry and Kawakami, 2017). This innovation often results in a major technological breakthrough, a new product, service, or 
a new business model, and needs long-term strategic planning because it involves inherent high uncertainty (Chen et al., 2017). The latter researchers also suggest that factors influencing high-end disruption include government support, external knowledge sources, strategic support, and the dominant position of R\&D.

Likewise, Hang et al. (2015) associate this kind of disruption with the creation of opportunities in the market. Innovations that create new markets and an new value networks while disrupting existing markets (Koh and King, 2017). A new market will not attempt to disrupt the mainstream market, therefore, its focus is on attracting new consumers or attracting consumers from the existing market whose needs cannot be met by existing products and these customers gradually choose the new market (Chen et al., 2017). 
The review above has sought to specify the types of DI identified in the literature. Figure

7 provides a summary of this typology. In this classification, and for the reasons discussed above, we include high-end disruption within new-market disruptions.

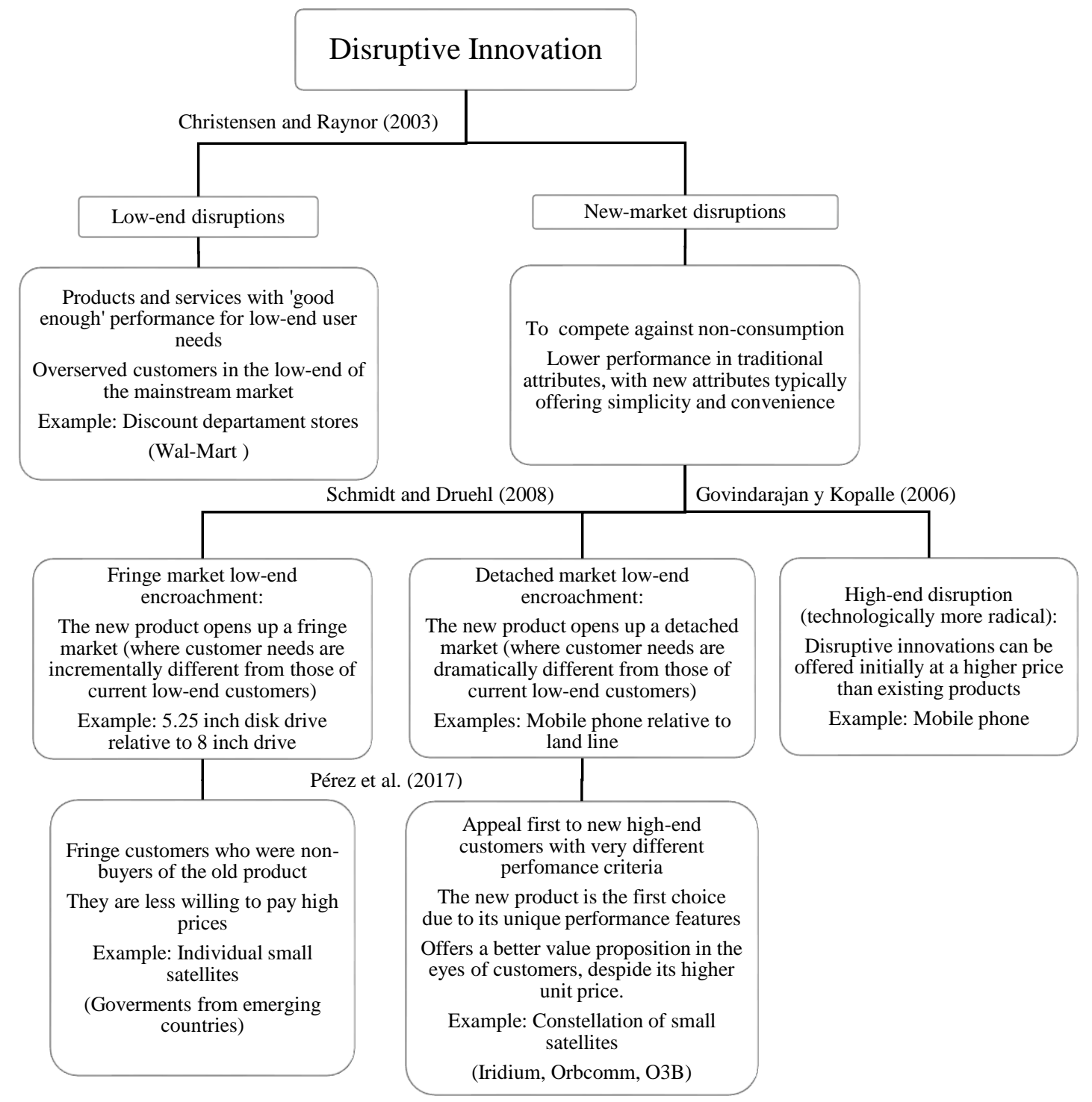

Figure 7. Types of disruptive innovation

Based on this typology of DI Table 3 shows more examples of each type arising from references in the literature. 


\begin{tabular}{lll}
\hline Disruptive innovations & Incumbent innovations & Guiding references \\
\hline Low-end disruptions & & \\
Amazon.com & Traditional bookstores \\
Endoscopic surgery & Traditional surgery \\
Minicomputers & Mainframe computer & Christensen and Raynor, 2003 \\
Google search engine & Yellow pages & \\
Email & Postal service & \\
Portable diabetes blood glucose meters & Large blood glucose testing machines & \\
Airbnb & Hotels & Yu and Hang, 2011 \\
Bakelite (a synthetic plastic) & Shellac & Guttentag, 2015 \\
New-market disruptions & & Dedehayir et al., 2017 \\
Personal computer & & \\
Transistor radio, transistor TV, Walkman, MiniDisc and Netflix & \\
TiVo (a start-up firm that pioneered the Digital Video Recorder) & & \\
5 G technology & & Christensen, 2003 \\
Uber & Christensen, 2015 \\
Microwave Oven & Ansari et al., 2016 \\
E-books & Suryanegara, 2016 \\
\hline & Tham, 2016 \\
\hline
\end{tabular}

Table 3. Some examples of disruptive innovation

Characteristics of DI. In recent years, many studies involving examples of DI have been published and many studies have identified their characteristics. For instance, Hadengue et al., (2017), Flavin (2016a), and Corsi and Di Minin (2014) highlight the characteristics of the disruptive technologies given by Christensen, who defines them as being "typically cheaper, simpler, smaller, and, frequently, more convenient to use than the existing product" (1997). Similarly, according to Tan et al., (2016) DI includes simpler products and services, smaller target markets, and lower gross margins. For Shin (2017) DI can never be achieved without lowering the cost of parts, reducing manufacturing costs and shortening the development time. DI is therefore less expensive, simpler, and more convenient (Kaissi et al., 2016). Usually, the disrupter offers lower performance and less functionality at a much lower price (Rafii and Kampas, 2002; Wan et al., 2015). Other researchers consider two particular characteristics: lower cost and lower performance (Allahar, 2017; Weeks, 2015; Yu and Hang, 2010). Steenhuis and Pretorius (2017) argue 
that "characteristics for disruptive technologies are that the capabilities initially are inferior to what incumbents use and that they deal with low-end customers or new market.” DI must be affordable with good enough performance (Yu and Hang, 2011). Others only consider one main characteristic, DI initially lacks the performance levels necessary to compete with the incumbents (Dedehayir et al., 2017).

Some studies specifically emphasise the characteristics of disruptive technologies, as the examples they provide are of this nature. Consistent with this notion, Yu and Hang (2011) found 11 categories (in this article we called them characteristics) examining relevant examples of technological DIs: small size, light weight, less power consumption, portability, customisation, ease of usage/design/production, time-saving, cost reduction, augment disruptive features, explore applicability and other unique values for specific products.

By way of summary, Agarwal et al. (2017) published an article in which they highlighted 32 characteristics of DI: accessible, advanced, affordable, alternative, basic, better, cheap, convenient, cost-effective, customised, environmental, flexible, frugality, improved, inexpensive, inferior, large-scale, low-cost, low-performance, modest, new, new market development, niche, no-frills, radical, resourceful, simple, small, social, sufficient, tailored and valuable. These characteristics were drawn from various examples and are useful in order to identify examples of this kind of innovation. Clearly, however, there are some characteristics that might not be measurable. It is thus necessary to evaluate characteristics among examples through new research. 
Table 4 illustrates the identified characteristics of some examples of DI.

\begin{tabular}{|c|c|c|c|}
\hline & Low-end disruption & & New-market disruption \\
\hline Example & Characteristics & Example & Characteristics \\
\hline \multirow{6}{*}{ Bakelite } & Available & \multirow{6}{*}{ Netflix } & Accessible \\
\hline & Ease of use & & Ease of use \\
\hline & Flexible & & Inmediate access \\
\hline & Inexpensive & & Inexpensive \\
\hline & & & Simple \\
\hline & & & $\begin{array}{l}\text { Other unique values for specific } \\
\text { functions }\end{array}$ \\
\hline \multirow{5}{*}{ Airbnb } & Accessible & \multirow{5}{*}{$\begin{array}{l}\text { Personal } \\
\text { computer }\end{array}$} & Available \\
\hline & Convenient & & Ease of use \\
\hline & Inexpensive & & Small size \\
\hline & Flexibility of location & & Portability \\
\hline & $\begin{array}{l}\text { Variety of accommodation } \\
\text { options }\end{array}$ & & Tailored to specific functions \\
\hline
\end{tabular}

Table 4. Characteristics of four disruptive innovations

On the whole, all these characteristics contribute to providing a clearer identification of DIs and are helpful for attracting a mixed market composed of a new market, low-end market, and, over time, a mainstream market. Managers aware of these characteristics are likely to adopt a new dominant logic that pursues new strategic actions.

\section{What behaviours are adopted by the actors associated with DI?}

The literature cited allows us to identify the behaviours adopted by the actors associated with DI. Therefore, in this section, specific attention is given to these behaviours. We divided our analysis into two sections: the first analyses and compares the behaviours adopted by incumbents and entrants, and the second identifies customer behaviours.

Behaviours adopted by incumbents and entrants toward DI. The process of DI considers the rivalry between the incumbent and the new entrant (Dedehayir et al., 2017). Managers in incumbent companies have often misunderstood the value of innovations by rivals 
(King and Baatartogtokh, 2015). We provide a summary in Table 5 of the findings described by Christensen and others involved in the field in order to illustrate the respective behaviours of incumbents and entrants who seek to conquer the main market (these include the references cited in Table 2, plus Gholampour, 2017; Govindarajan and Kopalle, 2006; Steenhuis and Pretorius, 2017).

\section{Incumbents' behaviours}

Have the resources, structure and customers of the mainstream market and lead the market

Focus on chasing higher profitability among the most demanding, and usually most profitable customers, exceeding or ignoring the needs of low-end segments

See the low-end segment as a small market and less profitable

Focus on improving their products or services for their current customers

Are dependent on the dominant customer segment

See that their customers are not attracted to the underperforming products or services of entrants, so do not focus on innovations of this kind

Unaware of the potential threat of DI, keep using their long-established capabilities

Begin to lose their customers, when the price and performance of the entrant's offer make it acceptable to mainstream customers or it is deemed comparatively better

Are forced to share the market, lose their leadership and even exit the market

\section{Entrants' behaviours}

Aware of inability to compete with incumbents

See an opportunity in the least-profitable segments (lowend customers), and overlooked low-end segments, developing a product or service that offers a better value proposition

Focus on understanding unmet needs of customers of given segment niche

Their products or services are, initially, inferior in those characteristics valued by mainstream customer or underperform for existing customers

Are initially independent on the dominant customer segment

Go unnoticed by potential competitors

Over time improve their products or services and finally deliver the performance that mainstream customers require

Begin to move up market to become competitive with market leaders

Are the new incumbents, offering products or services that are the best option for customers in the entire market

Table 5. Behaviours of incumbents and entrants in the disruptive innovation process

Analysis of incumbent behaviour. Established companies do not see early examples of DI as a threat because they are not yet competitive and cannot satisfy the needs of the mainstream customers; but, over time, improvements in their quality make them competitive and, eventually, they establish themselves as the first choice of the mainstream customers. Organisations offering DIs are rarely perceived as serious threats 
by dominant incumbents as they tend to be new entrants to the market (Kaissi et al., 2016). Indeed, many companies are not organised to give new ideas a chance, to recognise trend breaking points in the market, to adapt quickly to changing market circumstances, or to cause market changes in the first place (Markides, 1999). Incumbents need to be aware of DIs as soon as possible, since their early identification allows them to be more flexible or to change their plans and invest in a different way. DI requires flexibility, which means exploratory plans can be implemented and enough resources assigned to develop disruptive products or services. This being the case, DIs represent both a major challenge and an opportunity for many incumbents, who may have overlooked or misunderstood the importance of an emerging threat.

DIs result in business transformations in an organisation or industry and lead to major changes in current business processes that can displace existing dominant products on the market (Said and Adham, 2016). With the emergence of DI, every industry ecosystem undergoes major transformations and the best strategy is welcoming DI and exploiting it (Gholampour, 2017). To avoid being dethroned, Pérez et al. (2017) argue that incumbents need to identify new opportunities and develop plans that specifically focus on learning or discovery, building necessary partner bonds and disseminating information. Incumbents need to develop strategies regarding the unmet needs of non-customers without neglecting their own customers. It is worth noting that managers have to develop new professional competencies through long-life personal development and education (Mohelska and Sokolova, 2016), all the more so because DIs demand gathering knowledge and experimenting with new ideas (Kranz et al., 2016). 
In relation to the satisfaction of current customers and the dissatisfaction of noncustomers, Vecchiato (2017) suggests considering Maslow's (1954) hierarchy of needs, which highlights the fact that most people during their lives experience the need for both social relationships (love, friendship, intimacy) and for esteem (achievement and results, status and recognition, respect from others). We point out recognition, because one type of DI (low-end disruption) emerges when incumbents overlook lower customers, that is, customers who feel that their needs are not being satisfied with the incumbent's products or services, and on the other hand, we argue that status and recognition, achievement and results can be associated with new-market disruption (high-end disruption) because customers can feel identified with a product or service that responds to these needs.

Another factor with regards to DI is that incumbents need to explore the ways in which they can benefit from offering lower prices to costumers. In the business world, the goal of maximising shareholder value or maximising profits, often stymies innovations when firms are faced with DI (Yeh and Walter, 2016). Parry and Kawakami (2017) suggest that "a more effective approach might be to educate existing stakeholders about the ways they can benefit from lower prices to consumers." Industries that are currently based on higher volumes and low cost are susceptible to disruption (Steenhuis and Pretorius, 2017). The uncertainty over the revenues and profits associated with DI is likely to be one reason why incumbents do not support innovation of this kind. Decision-making processes for sustaining innovations are based on more precise data and accurate estimations of financial returns, however, DIs are very different, as neither revenues nor costs can be known, and innovation management based entirely on detailed plans and budgets is doomed to end in failure (Pérez et al., 2017). 
A DI does not always imply that entrants or emerging business will replace incumbents or traditional businesses, for example small vs large satellites (Martin-Rios and PargaDans, 2016; Pérez et al., 2017; Yu and Hang, 2010). Not all firms succumb to disruption, however; some are able to regain their dominance (Yeh and Walter, 2016). Dedehayir et al. (2017) argue that the new ecosystem can completely substitute for the incumbent, as was the case for the Bakelite vis-à-vis the Shellac ecosystem and in other cases, however (e.g. Canon versus Xerox, and microwave ovens versus traditional stoves), it appears that new and the incumbent ecosystems can co-exist for prolonged periods of time without substituting each other completely. In some cases, incumbents can "disrupt the disruption" by emphasising a new set of product attributes (Parry and Kawakami, 2017). During DI, creative development can result in the addition of a functionality that raises the innovation's value, but which costs more than the customers are willing to pay (Kranz et al., 2016). Disruptors are not necessarily start-ups or small firms (Pérez et al., 2017) and DI can just as well be developed by incumbents.

Identifying a DI is far from easy for incumbents as is their having to counter this new competition in the market when entrants start to conquer their mainstream customers with a DI. Hence, in this process an incumbent concerned with preventing a possible encroachment and dethronement by a DI can resort to the following strategies: identify the context of its inside market, measure the impact of an innovation originating from a low end or new market, increase control over its market share and mitigate the impact of a DI by creating an in-house $R \& D$ unit to develop products or services that reflect an indepth understanding of both customers and non-customers. 
Analysis of entrant behaviour. The main aim of entrants is to be accepted by the low-end or new market; they do not pursue big profitability. Entrants with DI, regardless of just how profitable the market might be, are initially interested only in testing whether their innovation is enough to be accepted and to survive. Entrants are capable of pursuing emerging growth markets, because their values can embrace small markets, their cost structure can admit lower margins and in the initial stages, their resources are largely its people (Isherwood and Tassabehji, 2016). DI provides an opportunity for SMEs to surpass the incumbents (Chen et al., 2017). Christensen's category of efficiency innovation means it is possible "to do more with less" (Flavin, 2016a) and entrants know full well how to apply this. As DI offers new characteristics (cheaper, smaller or easier to use) that are appreciated by the new or the low-end customers, incumbents don't bother to follow in its steps and an entrant with DI enjoys its growth without any threats (Ruan et al., 2014; Zhang and Zhang, 2017).

As soon as entrants begin to be accepted they improve their innovation so as to conquer the rest of the market (mainstream market), although they maintain the initially unique characteristics (simple, easy to use, price) that allowed them entry to the first market and to compete with existing business and to offer great opportunities for new profit growth. Entrants initially do not want to compete with incumbents who consider their innovations inferior. These innovations were disruptive in that they didn't address the next-generation needs of leading customers in existing markets (Gholampour, 2017).

Entrants are often start-ups-or entrepreneurs with few resources. As a result, the risk is lower. The resource dependencies of entrants compared to incumbents also provide a clear difference in entrepreneurial incentives (Berglund and Sandström, 2017). A 
company may appear mostly insignificant today; but may be poised to become much larger in a very short period (Guttentag, 2015). Entrants are freer to pursue their visions and to engage in entrepreneurial experimentation, consequently, they are also more inclined to interact with multiple potential customers (Berglund and Sandström, 2017). Disruption can take time - exactly how long depends on each specific case.

Disrupters find a way to turn non-consumers into consumers (Gholampour, 2017). Disruptors need to be more accommodative even as they attempt to transform the existing ecosystem (Ansari et al., 2016). Entrants succeed because, as dominant products evolve, they grow and become ever more sophisticated and expensive, until they exceed the needs of most customers (Contandriopoulos et al., 2016). Entrants have the capacity to meet customer's need for minor conditions or create new needs. Disruption works not by confronting established practice, but by doing something new (Flavin, 2016b). Another point to consider is that DI does not always imply that the entrant business will completely replace the incumbent business and the winners will take all (Yu and Hang, 2010).

Customer behaviour towards DI. Given that the success of any innovation depends on customer acceptance, in this section we shift our attention to address the question of why customers accept DIs.

In line with Christensen's initial theory, DIs offer different characteristics to those historically valued by mainstream customers. In the beginning, DIs are less valuable than those supported on the current market, but they are offered at a significantly better price, at least for customers willing to accept lower quality, or else they incorporate a new value proposition that make them unique. 
Under this approach, mainstream customers are unwilling to use a disruptive product in applications they know and understand (Bower and Christensen, 1995; Suryanegara, 2016). They feel comfortable and satisfied with the product or service provided by the incumbents and, so do not bother try out something new, let alone of lesser quality. Customers are empowered to share goods and services. For instance, the internet as a DI, means that customers are well informed about the characteristics of different products or services and, as such, it is an effective tool for customer empowerment, but there is a niche of customers who are dissatisfied with the price or with certain characteristics of the incumbents' offer. Levina (2017) argues that corporations anticipate consumers "needs, wants, and whims" and firms validate their desires and actions. Performance oversupply attracts customers to products that pay greater attention to price or new criteria that have, up to that juncture, been considered secondary.

As a consequence, DIs tend to be an answer to customer dissatisfaction because they appeal to customers from low-end markets who demand lower prices and prefer to buy simpler products or services; on the other hand, DIs can appeal to new consumers who previously consumed neither in the mainstream nor in the low-end markets, meaning that they experience the innovation for the first time. DIs have very different characteristics from the products or services available previously, which are appreciated by customers, as DIs improve while retaining their main characteristics of affordability, simplicity, price, and so on. These characteristics and their enhancements are key in order to seduce mainstream customers. In other words, DIs upset the market by combining low prices with high-quality and other unique characteristics that make them the best option on the market. As a result, the consumption of DIs is more affordable and available at all levels, and so they are less hierarchical. 
Table 6 summarises, and contrasts customers behaviours based on our review of this framework.

\begin{tabular}{|c|c|c|}
\hline \multicolumn{3}{|c|}{ Customers' behaviours } \\
\hline $\begin{array}{c}\text { Customers from low-end } \\
\text { market }\end{array}$ & Customers from new-market & $\begin{array}{c}\text { Customers from mainstream- } \\
\text { market }\end{array}$ \\
\hline $\begin{array}{l}\text { Are over satisfied by existing } \\
\text { products or services }\end{array}$ & $\begin{array}{l}\text { Are attracted by new products or } \\
\text { services in the market }\end{array}$ & $\begin{array}{l}\text { Reject products or services with } \\
\text { good enough performance }\end{array}$ \\
\hline $\begin{array}{l}\text { Are less sophisticated and less } \\
\text { demanding on quality }\end{array}$ & $\begin{array}{l}\text { Have a willingness to experiment } \\
\text { and keep trying new generations of } \\
\text { products or services }\end{array}$ & $\begin{array}{l}\text { Are more demanding on quality } \\
\text { and less demanding on price }\end{array}$ \\
\hline $\begin{array}{l}\text { Prefer to buy affordable products } \\
\text { or services with good enough } \\
\text { performance }\end{array}$ & Discover new needs & $\begin{array}{l}\text { Buy products or services with } \\
\text { reasonably high quality and } \\
\text { appreciate the improvement of the } \\
\text { performance of the products or } \\
\text { services that they are used to } \\
\text { buying }\end{array}$ \\
\hline $\begin{array}{l}\text { Seek the best satisfaction at the } \\
\text { lowest possible price }\end{array}$ & $\begin{array}{l}\text { Don't consider necessarily the } \\
\text { products or services' prices to be } \\
\text { accepted }\end{array}$ & $\begin{array}{l}\text { Consider the incumbents' well- } \\
\text { respected reputation and have } \\
\text { reliability issues about adopting } \\
\text { innovations that are not from } \\
\text { incumbents }\end{array}$ \\
\hline $\begin{array}{l}\text { Are considered the least profitable } \\
\text { segment of the market }\end{array}$ & $\begin{array}{l}\text { Encourage a broad } \\
\text { experimentation with customers } \\
\text { from low-end market and } \\
\text { mainstream market }\end{array}$ & $\begin{array}{l}\text { Are considered the most profitable } \\
\text { segment of the market }\end{array}$ \\
\hline $\begin{array}{l}\text { Are the first in accepting low-end } \\
\text { disruptions }\end{array}$ & $\begin{array}{l}\text { Are new consumers of new- } \\
\text { market disruptions }\end{array}$ & $\begin{array}{l}\text { Only accept disruptive innovations } \\
\text { when their quality and new } \\
\text { characteristics are better than } \\
\text { traditional products or services }\end{array}$ \\
\hline $\begin{array}{l}\text { Satisfy their unmet needs into the } \\
\text { market }\end{array}$ & $\begin{array}{l}\text { Encourage new requirement and } \\
\text { challenges }\end{array}$ & $\begin{array}{l}\text { Have enough reliance on disruptive } \\
\text { innovations and are willing to buy } \\
\text { such innovations }\end{array}$ \\
\hline
\end{tabular}

Table 6. Behaviours of customers in the disruptive innovation process

DI requires customers to be willing to try out the innovation. New models and technologies cannot be disruptive in an environment that is resisting change (Hans et al., 2017). New technologies often require altered behaviour on behalf of customers, endusers and other critical stakeholders in order to be adopted (Berglund and Sandström, 
2017). The success of DIs depends on customers being willing to change their preferences, take a risk or satisfy their curiosity and whims.

Therefore, a successful DI requires a receptive audience. Everett Rogers (2003) in his seminal book on "Diffusion of Innovations" argues that "Innovativeness is the degree to which an individual or other unit of adoption is relatively earlier in adopting new ideas than the other members of a system." In this approach consumers are categorised according to the point that an innovation is adopted. Rogers proposed five adopter categories: (1) innovators, (2) early adopters, (3) early majority, (4) late majority, and (5) laggards. Figure 8 highlights the main characteristics of each category. Users play several roles in the information and advice about the innovation dissemination.

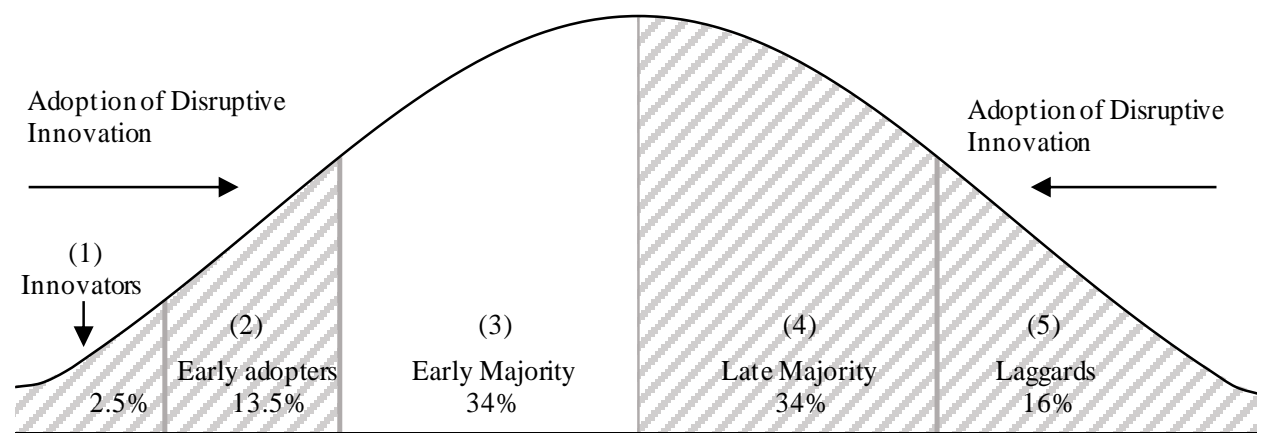

1 First to adopt the innovation, they are venturesome, develop cosmopolite social relationships with capacity to absorb possible losses from an unprofitable innovation, ability to understand and apply complex technical knowledge and able to cope with a high degree of uncertainty about an innovation. They have a desire for the rash, the daring, and the risky. Play a gatekeeping role in the flow of new ideas into a system.

2 Visionaries, they are localities more than any other group, and have the highest degree of opinion leadership in most systems. Potential adopters look to early adopters for advice and information about an innovation. They help trigger the critical mass when they adopt an innovation.

3 Adopt new ideas just before the average member of a system. They may deliberate for some time before completely adopting a new idea. They follow with deliberate willingness in adopting innovations but seldom lead.

4 Adopt new ideas just after the average member of a system. Adoption may be both an economic necessity and the result of increasing peer pressures. Innovations are approached with a sceptical and cautious air. Their relatively scarce resources mean that most of the uncertainty about a new idea must be removed before the late majority feel that it is safe to adopt.

5 They possess almost no opinion leadership. Many are near isolates in the social networks of their system. Their innovation decision process is relatively lengthy. Their resistance to innovations is because their resources are limited, and they must be certain that a new idea will not fail before they can adopt. The laggard's precarious economic position forces the individual to be extremely cautious in adopting innovations.

Figure 8. Rogers' innovation adoption curve - 2003 
In line with Rogers' categories, we argue that initially four adopter categories can be associated with DIs:

Innovators. Given their interest in new ideas, innovators are active information seekers about new ideas and have the ability to understand and apply complex technical knowledge. They are willing to accept an occasional setback when a new idea proves unsuccessful. Initially a DI is not a high-quality product or service, but it introduces new characteristics or creates new needs.

Early adopters. Govindarajan et al. (2006) suggest that in this category high end disruption (innovations that can be offered initially at a higher price than existing products) "technologically radical innovations primarily appeal to the early-adopter category at the time of product introduction and over time appeal more to the mainstream market." Rogers (2003) suggests that innovators and early adopters start using a new idea on a more tentative basis than do laggards. Sometimes the knowledge of an innovation creates a need for it. Customers who are selective, accept the price and begin adopting the DI.

Laggards. Because low-end disruptions tend to focus on customers with lower socioeconomic status, laggards are more sensitive to price, and many are overlooked by the market. They are more resistant to change and harder to influence but they are often the first to adopt a DI. A detached-market may also be found in this group. Taking into account that new-market disruptions compete against non-consumption (Christensen and Raynor, 2003). A DI can change their behaviour markedly.

Late majority. This group adopts DIs due to their limited resources. DI introduces a lower price and new characteristics, so this adopter category does not have to wait very long to feel it is safe to adopt. Customers find it convenient to use the innovation. 
Consistent with these approaches, it is worth noting that the four adopter categories above are the first to adopt DIs. DI breaks Rogers' order of adopter categories its introduction can, to quote Said and Adham (2016) "create disorder in the market."

The availability of a low-cost product and the presence of many first-time consumers with a desire for experimentation (Wan et al., 2015) reduce customer indifference and scepticism, as they are being seduced by its inherent characteristics: ' being good enough', low price, simple, and easy to use. Customers are thus able to do something they had not been able to do before (Flavin, 2016b). As such, the risk is low, which makes acceptance much easier for most adopters. The striped areas in Figure 8 represent the initial adopters of a DI.

In the case of the early majority, one of the five adopter categories, are the last to adopt DIs as their innovation-decision period is relatively longer than that of the other four adopter categories (i.e., the innovators, the early adopters, the laggards and the late majority). As noted in Figure 8, the "early majority may deliberate for some time before completely adopting a new idea," and their resistance to DIs is because they embrace an innovation as and when they understand how it fits into their lives and can appreciate the benefits and quality of the innovation. This category can be associated with mainstream customers.

However, the key issues affecting innovation adoption also need to be examined in different contexts. DI requires taking into account issues such as consumer lifestyle, consumer perceptions and consumer behaviour. Parry and Kawakami (2017) argue that 
consumer preferences play an important role in the DI adoption and Zhang and Zhang, (2017) claim that it is knowledge.

\section{Discussion}

The purpose of our article is to provide a better understanding of DI theory, offering several significant insights for researchers and practitioners. Our analysis of DI has been developed through a step-by-step process in order to contribute to a more effectively understanding of important aspects concerning DI.

We have answered to our two research questions: (1) What is DI? and 2) what behaviours are adopted by the actors associated with DI? In other words, the analysis presented herein highlights the evolution (antecedents and definitions), types, characteristics and behaviours of incumbents, entrants and customers with respect to DI theory. Thus, this work can help researchers and managers understand what is meant by a DI and it could be helpful for them to keep abreast of the most important recent lines of this theory.

In this study, we have examined the antecedent of this theory and clearly identified two key milestones related to the birth of it. However, concerning the definition of DI and based on our analysis of 17 definitions, grouped into 3 approaches: as a process, low-cost model, and the role of technology to develop DIs, a consensus has yet to be reached. Many studies apply either Christensen's first or second definition, while others mix the two and add particular specifications from their own study, depending on the examples they analyse. Additionally, the meaning of the term 'disruptive' is widely used, but little regard seems to have been paid to the core tenets of this theory. Despite these inherent 
problems, our analysis provides a definition of DI. There is no doubt that unambiguously defining a DI is essential for both academic and practical reasons (Nagy et al., 2016).

On the other hand, we described a typology of disruptions: low-end disruption and newmarket disruption, in order to identify whether a DI tends to focus on an underserved market or create a new consumption. Likewise, this research identified relevant characteristics of DI, Christensen (1997) defines them as being "typically cheaper, simpler, smaller, and, frequently, more convenient to use than the existing product" but there are many others. Up to 32 characteristics were identified by Agarwal et al. (2017). All of these characteristics have important implications for business strategy and innovation management. Managers could use this information so as to develop or to identify examples that present disruptive potential and rethink their strategies for responding to DI.

Our analysis also identified the behaviours adopted by incumbents, entrants and customers in DI processes. With the advent of a DI, more and more incumbents are forced to change their business models and to move away from their traditional way of thinking altogether. Several important behaviours of incumbents were analysed, which are useful for explaining challenges, organizational changes and opportunities that emerge when incumbents are faced with a DI. They need to re-examine their role respect to the unmet needs of non-consumers and the satisfactions of current customers. They must be constantly monitoring their competitors as well as developing new innovations, although some existing sectors or individual incumbents are likely to resist any disruptions to their market. 
Entrants offering a DI compete with incumbents, winning larger customer shares by offering a lower price, better performance, and a faster, more convenient, more effective and more customised service or product. A DI can be better than the existing products or services, and not just for one group of customers, but for all, or nearly all, customers. DI first wins over the least demanding customers (low-end disruptions) and/or compete against non-consumption (new-market disruptions) and over time successfully persuades the most demanding. Indeed, the role played by customers is critical in the DI process, and here the reaction of product users is fundamental. Customers consider a DI with its unique characteristics as their first choice and so break with traditional consumer behaviour.

Our critical literature review examined the behaviours of customers from low-end market, new-market and mainstream market to understand in each case why these customers prefer to choose a DI. As DI requires a receptive customer, following Rogers (2003) we identified that four adopter categories can be associated with DIs: innovators, early adopters, laggards and late majority. These behaviours and categories associated with DI can help managers to rethink their strategies for responding to requirements of customers. To satisfy customer demands, firms need to produce more products or services that closely meet the needs of customers. Challenging the firms to produce more creative solutions in order to respond to customer problems, wants, whims and suggestions. A deep knowledge of customer behaviours can help firms to develop new strategies in efforts to satisfy unmet needs of customers.

In short, as this innovation is adopted, many businesses are put under pressure to demonstrate their capacity to compete and survive in a global economy. Thus, DI changes 
the traditional behaviours of customers, incumbents and the market. Firms become aware that the DI is associated with discovery and the creation of opportunities and that it represents a call for action and change, if they hope to be able to explore the opportunities for offering the best product or service. DIs involve time, cost and performance, new rules, new companies, and new challenges. Therefore, DI impacts on a firm's performance, effecting people, society and financial performance, since it satisfies the unmet needs of non-consumers or creates new needs, by tying its innovation to exponential growth and falling costs.

DI comes to replace or to change traditional management decisions and, so, managers have to develop new skills, one of which is the ability to determine what is technologically possible and what is culturally acceptable in their business sector, that is, the need to provide insights into the gap between technology, customers preferences, government regulation, and culture. DI requires that business models be flexible; it is not only incumbents who are unwilling to change, but customers too.

The findings show that this theory can be identified, but it is complex, most likely due to the complexity of the phenomenon. Overall, our results open up a clear and comprehensive picture of DI theory. It will provide readers with significant and thoughtful material that illustrates the challenges and the rewards of striving toward DI and cultural practice in innovation.

\section{Conclusion}

DI involves a paradigm shift in the way business is done, transforming many businesses, forcing incumbents to take into account market segments that they previously ignored, 
and to take seriously rivals who at the outset appear so insignificant that they do not constitute any kind of threat. DI pushes to set up new business models and to review or re-invent ongoing business in order to survive and grow. As business environments are subject to constant change, companies in highly competitive markets face many challenges, as well as opportunities, and increasingly fierce competition. One of the major issues for incumbents and entrants is to develop DI and thus avoid being unnoticed in the market. Contrary to their expectations of customers in the mainstream market (who look for high quality in products or services, and for whom the price is apparently less important), DI surprises them and seduces new customers, in some cases offering a high price, high quality and unique characteristics, and in others less quality, enough performance, lower price and unique characteristics (in this case the quality improves over time). Customer resistance to DI is thus too low. The impact of DI cannot be ignored, and it has become a critical concern for both researchers and practitioners.

The purpose of this article was to carry out a critical review so as to understand what DI is. In doing so, we examined 67 articles from the Web of Science, from 1964 to 2017. Our research highlights the various insights into this theory, including its origin, evolution, and current knowledge. Based on the critical review presented in this article and the analysis provided, Table 7 briefly summarises a list of potential approaches to this theory and notes some possible features for consideration, as mentioned above. This table allows the reader to understand the potential directions of this innovation from a wider perspective. 


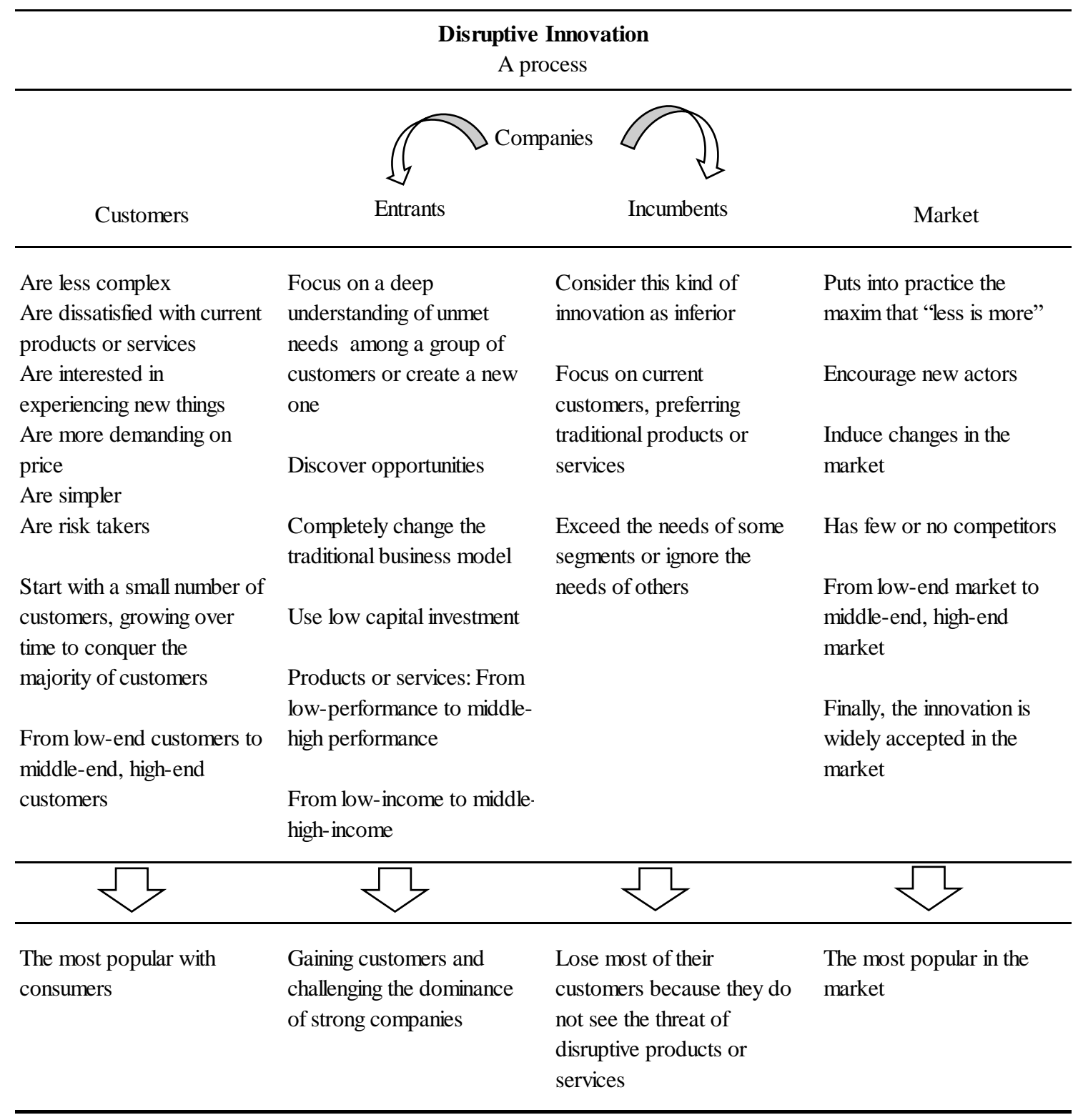

Table 7. Summary of potential approaches to disruptive innovation

The findings of this research indicate the need for more studies on the meaning of DI, in order to reinforce and reduce the state of ambiguity of this theory within the academic field. This article encourages future research opportunities and moves the discussion of this theory forward, as many researchers from different disciplines currently struggle to identify and develop in-depth knowledge of this type of innovation, and it offers answers as to why firms need to change their business goal from maximising profits to satisfying consumers. 


\section{References}

Abernathy, W.J. and Clark, K.B. (1985), "Innovation: Mapping the winds of creative destruction”, Research Policy, Vol. 14, pp. 3-22.

Agarwal, N., Grottke, M., Mishra, S. and Brem, A. (2017), "A systematic literature review of constraint-based innovations: State of the art and future perspectives", IEEE Transactions on Engineering Management, Vol. 64 No. 1, pp. 3-15.

Allahar, H. (2017), “Academic Publishing, Internet Technology, and Disruptive Innovation”, Technology Innovation Management Review, Vol. 7 No. 11, pp. 4756.

Ansari, S., Garud, R. and Kumaraswamy, A. (2016), "The disruptor's dilemma: TiVO and the U.S. television ecosystem", Strategic Management Journal, Vol. 37 No. 9, pp. 1829-1853.

Assink, M. (2006), "Inhibitors of disruptive innovation capability: A conceptual model”, European Journal of Innovation Management, Vol. 9 No. 2, pp. 215-233.

Berglund, H. and Sandström, C. (2017), “A new perspective on the innovator's dilemma - exploring the role of entrepreneurial incentives", International Journal of Technology Management, Vol. 75 No. 1/2/3/4, pp. 142-156.

Bower, J.L. and Christensen, C.M. (1995), "Disruptive technologies: Catching the wave", Long Range Planning, Vol. 28 No. 2, pp. 43-53.

Chen, J., Zhu, Z. and Zhang, Y. (2017), "A study of factors influencing disruptive innovation in Chinese SMEs", Asian Journal of Technology Innovation, Vol. 25 No. 1, pp. 140-157.

Christensen, C.M. (1997), The Innovator's Dilemma: When NewTechnologies Cause Great Firms to Fail, Harvard Business School Press, Boston, MA.

Christensen, C.M. (2006), "The ongoing process of building a theory of disruption", Journal of Product Innovation Management, Vol. 23, pp. 39-55.

Christensen, C.M. and Bower, J.L. (1996), "Customer power, strategic investment, and the failure of leading firms", IEEE Engineering Management Review, Vol. 24 No. 4, pp. 69-86.

Christensen, C.M. and Raynor, M.E. (2003), The Innovator's Solution: Creating and Sustaining Successful Growth, Harvard Business School Press, Boston, MA.

Christensen, C.M., Raynor, M.E. and McDonald, R. (2015), "What is disruptive innovation?", Harvard Business Review, Vol. 93 No. 12, pp. 44-53.

Contandriopoulos, D., Brousselle, A., Breton, M., Sangster-Gormley, E., Kilpatrick, K., Dubois, C.-A., Brault, I., et al. (2016), "Nurse practitioners, canaries in the mine of primary care reform", Health Policy, Vol. 120 No. 6, pp. 682-689.

Corsi, S. and Di Minin, A. (2014), "Disruptive innovation in reverse: Adding a geographical dimension to disruptive innovation theory", Creativity and Innovation Management, Vol. 23 No. 1, pp. 76-90.

Crockett, D.R., McGee, J.E. and Payne, G.T. (2013), "Employing new business divisions to exploit disruptive innovations: The interplay between characteristics of the corporation and those of the venture management team", Journal of Product Innovation Management, Vol. 30 No. 5, pp. 856-879. 
Danneels, E. (2004), "Disruptive technology reconsidered: A critique and research agenda", Journal of Product Innovation Management, Vol. 21, pp. 246-258.

Dedehayir, O., Ortt, J.R. and Seppänen, M. (2017), "Disruptive change and the reconfiguration of innovation ecosystems", Journal of Technology Management and Innovation, Vol. 12 No. 3, pp. 9-21.

Dijk, M., Wells, P. and Kemp, R. (2016), "Will the momentum of the electric car last? Testing an hypothesis on disruptive innovation", Technological Forecasting and Social Change, Vol. 105, pp. 77-88.

Flavin, M. (2016a), “Technology-enhanced learning and higher education", Oxford Review of Economic Policy, Vol. 32 No. 4, pp. 632-645.

Flavin, M. (2016b), "Disruptive conduct: the impact of disruptive technologies on social relations in higher education", Innovations in Education and Teaching International, Vol. 53 No. 1, pp. 3-15.

Gholampour, M. (2017), "Disruptive innovation in media industry ecosystem and need for improving managerial cognitive capabilities in polymediation era", Cogent Business and Management, Cogent, Vol. 4 No. 1, pp. 1-24.

Govindarajan, V. and Kopalle, P.K. (2006), "The Usefulness of measuring disruptiveness of innovations ex post in making ex ante predictions", Journal of Product Innovation Management, Vol. 23, pp. 12-18.

Govindarajan, V., Kopalle, P.K. and Danneels, E. (2011), "The effects of mainstream and emerging customer orientations on radical and disruptive innovations", Journal of Product Innovation Management, Vol. 28 No. S1, pp. 121-132.

Guo, J., Tan, R., Sun, J., Cao, G. and Zhang, L. (2016), “An approach for generating design scheme of new market disruptive products driven by function differentiation", Computers and Industrial Engineering, Elsevier Ltd, Vol. 102, pp. 302-315.

Gurca, A. and Ravishankar, M.N. (2016), “A Bricolage Perspective on Technological Innovation in Emerging Markets", IEEE Transactions on Engineering Management, Vol. 63 No. 1, pp. 1-14.

Guttentag, D. (2015), “Airbnb : Disruptive innovation and the rise of an informal tourism accommodation sector", Current Issues in Tourism, Vol. 18:12, pp. 11921217.

Hadengue, M., de Marcellis-Warin, N. and Warin, T. (2017), "Reverse innovation: A systematic literature review", International Journal of Emerging Markets, Vol. 12 No. 2, pp. 142-182.

Hahn, F., Jensen, S. and Tanev, S. (2014), "Disruptive innovation vs disruptive technology: The disruptive potential of the value propositions of 3D printing technology startups", Technology Innovation Management Review, Vol. 4 No. 12, pp. 27-36.

Hang, C.C., Garnsey, E. and Ruan, Y. (2015), “Opportunities for disruption”, Technovation, Elsevier, Vol. 39 No. 40, pp. 83-93.

Hans, P.K., Gray, C.S., Gill, A. and Tiessen, J. (2017), "The provider perspective: Investigating the effect of the Electronic Patient-Reported Outcome (ePRO) mobile application and portal on primary care provider workflow", Primary Health Care Research and Development, Vol. 19 No. 2, pp. 151-164. 
Henderson, R.M. and Clark, K.B. (1990), “Architectural innovation: The reconfiguration of existing product technologies and the failure of established firms", Administrative Science Quarterly, Vol. 35 No. 1, pp. 9-30.

Hogarth, S. (2017), "Valley of the unicorns: Consumer genomics, venture capital and digital disruption", New Genetics and Society, Vol. 36 No. 3, pp. 250-272.

Isherwood, A. and Tassabehji, R. (2016), “A case analysis of managing 'Maverick' innovation units”, International Journal of Information Management, Vol. 36 No. 5, pp. 793-798.

Kaissi, A., Antonio, S., Shay, P. and Roscoe, C. (2016), "Hospital systems, convenient care strategies, and healthcare reform", Journal of Healthcare Management, Vol. 31 No. 2, pp. 148-63.

King, A.A. and Baatartogtokh, B. (2015), "How useful is the theory of disruptive innovation?", MIT Sloan Management Review, Vol. 57 No. 1, pp. 77-90.

Koh, E. and King, B. (2017), "Accommodating the sharing revolution: a qualitative evaluation of the impact of Airbnb on Singapore's budget hotels", Tourism Recreation Research, Vol. 42 No. 4, pp. 409-421.

Kranz, J.J., Hanelt, A. and Kolbe, L.M. (2016), "Understanding the influence of absorptive capacity and ambidexterity on the process of business model change the case of on-premise and cloud-computing software", Information Systems Journal, Vol. 26 No. 5, pp. 477-517.

Kushins, E.R., Heard, H. and Weber, J.M. (2017), "Disruptive innovation in rural American healthcare: The physician assistant practice", International Journal of Pharmaceutical and Healthcare Marketing, Vol. 11 No. 2, pp. 165-182.

Levina, M. (2017), "Disrupt or die: Mobile health and disruptive innovation as body politics", Television and New Media, Vol. 18 No. 6, pp. 548-564.

Lewis, D.W. (2012), "The inevitability of open access", College \& Research Libraries, Vol. 73 No. 5, pp. 493-506.

MacFeely, S. (2016), "The continuing evolution of official statistics: Some challenges and opportunities.", Journal of Official Statistics (JOS), Vol. 32 No. 4, pp. 789810.

Markides, C. (2006), "Disruptive innovation: In need of better theory", Journal of Product Innovation Management, Vol. 23, pp. 19-25.

Markides, C.C. (1999), “A dynamic view of strategy”, Sloan Management Review, Vol. 40 No. 3, pp. 55-63.

Martin-Rios, C. and Parga-Dans, E. (2016), "The early bird gets the worm, but the second mouse gets the cheese: Non-technological innovation in creative industries", Creativity and Innovation Management, Vol. 25 No. 1, pp. 6-17.

Maslow, A. (1954), Motivation and Personality, Harper and Row, New York.

Mohelska, H. and Sokolova, M. (2016), "Smart, connected products change a company's business strategy orientation", Applied Economics, Vol. 48 No. 47, pp. 4502-4509.

Nagy, D., Schuessler, J. and Dubinsky, A. (2016), "Defining and identifying disruptive innovations", Industrial Marketing Management, Vol. 57, pp. 119-126.

Ordanini, A., Rubera, G. and DeFillippi, R. (2008), “The many moods of inter- 
organizational imitation: A critical review", International Journal of Management Reviews, Vol. 10, pp. 375-398.

Parry, M.E. and Kawakami, T. (2017), "The encroachment speed of potentially disruptive innovations with indirect network externalities: The case of e-readers", Journal of Product Innovation Management, Vol. 34 No. 2, pp. 141-158.

Pérez, L., Dos Santos Paulino, V. and Cambra-Fierro, J. (2017), "Taking advantage of disruptive innovation through changes in value networks: insights from the space industry", Supply Chain Management: An International Journal, Vol. 22 No. 2, pp. 97-106.

Podsakoff, P.M., Mackenzie, S.B., Bachrach, D.G. and Podsakoff, N.P. (2005), "The influence of management journals in the 1980s and 1990s", Strategic Management Journal, Vol. 26 No. 5, pp. 473-488.

Rafii, F. and Kampas, P.J. (2002), "How to identify your enemies before they destroy you”, Harvard Business Review, Vol. 80 No. 11, pp. 115-123.

Rambe, P. and Moeti, M. (2017), "Disrupting and democratising higher education provision or entrenching academic elitism: Towards a model of MOOCs adoption at African universities", Educational Technology Research and Development, Springer US, Vol. 65 No. 3, pp. 631-651.

Rogers, E.M. (2003), Diffusion of Innovations, (5th ed.) Free Press, New York.

Ruan, Y., Hang, C.C. and Wang, Y.M. (2014), “Government's role in disruptive innovation and industry emergence: The case of the electric bike in China", Technovation, Vol. 34 No. 12, pp. 785-796.

Said, M.F. and Adham, A.A. (2016), "Is a mobile phone a disruptive innovation in the workplace?”, Gadjah Mada International Journal of Business, Vol. 18 No. 2, pp. $131-151$.

Savino, T., Messeni Petruzzelli, A. and Albino, V. (2017), "Search and Recombination Process to Innovate: A Review of the Empirical Evidence and a Research Agenda", International Journal of Management Reviews, Vol. 19 No. 1, pp. 5475 .

Schmidt, G.M. and Druehl, C.T. (2008), "When is a disruptive innovation disruptive?", Journal of Product Innovation Management, Vol. 25, pp. 347-369.

Schumpeter, J. (1942), Capitalism, Socialism, and Democracy, (3rd ed.) Harper and Brothers, New York.

Shin, D.-I. (2017), "An exploratory study of innovation strategies of the internet of things SMEs in South Korea", Asia Pacific Journal of Innovation and Entrepreneurship, Vol. 11 No. 2, pp. 171-189.

Steenhuis, H.-J. and Pretorius, L. (2017), "The additive manufacturing innovation: A range of implications", Journal of Manufacturing Technology Management, Vol. 28 No. 1, pp. 122-143.

Suryanegara, M. (2016), "5G As disruptive innovation: Standard and regulatory challenges at a country level”, International Journal of Technology, Vol. 4, pp. 635-642.

Tan, A., Ashrafian, H., Scott, A.J., Mason, S.E., Harling, L., Athanasiou, T. and Darzi, A. (2016), "Robotic surgery: disruptive innovation or unfulfilled promise? A systematic review and meta-analysis of the first 30 years", Surgical Endoscopy, 
Springer US, Vol. 30 No. 10, pp. 4330-4352.

Taylor, A. (2017), "Perspectives on the university as a business: The corporate management structure, neoliberalism and higher education", Journal for Critical Education Policy Studies, Vol. 15 No. 1, p. 117.

Tellis, G.J. (2006), “Disruptive technology or visionary leadership?”, Journal of Product Innovation Management, Vol. 23 No. 1, pp. 34-38.

Tham, A. (2016), "When Harry met Sally: Different approaches towards Uber and AirBnB - an Australian and Singapore perspective", Information Technology and Tourism, Springer Berlin Heidelberg, Vol. 16 No. 4, pp. 393-412.

Vecchiato, R. (2017), "Disruptive innovation, managerial cognition, and technology competition outcomes", Technological Forecasting and Social Change, Vol. 116, pp. 116-128.

Wan, F., Williamson, P.J. and Yin, E. (2015), “Antecedents and implications of disruptive innovation: Evidence from China”, Technovation, Vol. 39 No. 40, pp. 94-104.

Weeks, M.R. (2015), "Is disruption theory wearing new clothes or just naked? Analyzing recent critiques of disruptive innovation theory", Innovation: Management, Policy and Practice, Vol. 17 No. 4, pp. 417-428.

White, G.R.T. (2017), "Future applications of blockchain in business and management: A Delphi study", Strategic Change, Vol. 26 No. 5, pp. 439-451.

Yeh, S.-T. and Walter, Z. (2016), "Determinants of service innovation in academic libraries through the lens of disruptive innovation", College \& Research Libraries, Vol. 77 No. 6, pp. 795-804.

$\mathrm{Yu}, \mathrm{D}$. and Hang, C.C. (2010), "A reflective review of disruptive innovation theory", International Journal of Management Reviews, Vol. 12 No. 4, pp. 435-452.

Yu, D. and Hang, C.C. (2011), "Creating technology candidates for disruptive innovation: Generally applicable R \& D strategies", Technovation, Vol. 31 No. 8, pp. 401-410.

Zhang, W. and Zhang, Q. (2017), "Exploring antecedent difference between early and late adopters of disruptive innovation in e-business microcredit context: Evidence from China", International Journal of Innovation and Technology Management, Vol. 14 No. 06, pp. 1750032-1750061. 